\title{
Characterisation of activity based costing on remanufacturing crankshaft
}

\author{
M. Y. Abu ${ }^{1 *}$, K. R. Jamaludin ${ }^{2}$ and M. A. Zakaria ${ }^{1}$ \\ ${ }^{1}$ Faculty of Manufacturing Engineering, Universiti Malaysia Pahang, \\ 26600 Pekan, Pahang, Malaysia \\ *Email: myazid@ump.edu.my \\ Phone: +6094245815; Fax: +6094245888 \\ ${ }^{2}$ UTM Razak School of Engineering and Advanced Technology, \\ Universiti Teknologi Malaysia, \\ 54100 Kuala Lumpur, Malaysia
}

\begin{abstract}
Traditional cost accounting applied by most remanufacturing industries assumes that manufacturing overheads are driven by the volume of production. However, this would not give a good measure of the actual manufacturing cost per unit because the overheads should actually be apportioned over the number of activities that are required to perform. Eventually, the cost of remanufactured crankshaft becomes obviously incorrect while the profitability becomes vague. The aim of this work is to estimate the cost of remanufactured crankshaft using activity based costing. The overhead costs are apportioned to activity drivers in accordance with the way resources are consumed and then, the overhead costs are apportioned from each activity driver to each cost object in proportion to the amount of the cost driver consumed by the product. The proposed method is validated by an industrial practitioner and expected to be able to serve as a useful approach because it produces a cost with accurate allocation of overhead, provides cost information on the cost drivers and produces accurate manufacturing cost and profitability information. This work is also supported by the Ministry of International Trade and Industry of Malaysia by proposing accurate allocation of overhead to strengthen the national remanufacturing policies for the development of remanufacturing industries as these industries need to sustain their end of life products.
\end{abstract}

Keywords: Remanufacturing; crankshaft; traditional cost accounting; activity based costing.

\section{INTRODUCTION}

Remanufacturing is a process of transforming a used product to a like-new condition by rebuilding its components back to its design specifications, replacing unbuildable components and carrying a matching warranty period as to a brand new one manufactured by the original equipment manufacturer. During the process, the product is completely dismantled through a series of industrial process in a factory environment. Some usable components are cleaned in particular ways and subsequently stored into the component inventory. Then, they are carefully inspected against the original specifications and testing is performed under manufacturer's specification and original production standards [1]. It is also an effective strategy for promoting sustainability in the automotive industry because compared to new products, remanufactured products cost only 50\% of new 
products, while utilising $60 \%$ of energy and $70 \%$ of materials [2-4]. TCA which allocated the manufacturing overhead to product using a predetermined overhead rate is believed to be obsolete in modern manufacturing environments. However, the method is still being used widely by remanufacturing industries by assuming that the manufacturing overhead is driven by the volume of production. However, this does not provide a good measure of the actual manufacturing cost per unit and not effective as the overhead should instead be apportioned over the number of activities that are required to perform. Meanwhile, ABC could improve the accuracy of cost data and further control the project costs because of its activity characteristics [5]. The application of $\mathrm{ABC}$ has been reported in organisational [6], hospital [7], supply chain [8], cellular manufacturing [9], farm management [10], transportation $[11,12]$ and decision making $[13,14]$ environments. In order to develop strategies to control the costs in small and medium-sized firms, [15] analysed the impact, penetration and characteristics of ABC. Tsai et al. [16] presented a model that supports direct costing and $\mathrm{ABC}$ methodologies which offers precise information with general costs allocation procedures based on the consumption of activities. In order to improve the green manufacturing technologies, Schulze et al. [17] assessed how the integration of $\mathrm{ABC}$, theory of constraints and mixed-integer programming model can assist in making decisions to analyse the profitability of a product-mix decision. Increasing carbon emission as an important consideration in sustainable environmental development, [18] proposed a 0-1 mixed integer programming decision model using an $\mathrm{ABC}$ and life cycle assessment approach which produced a more accurate allocate resource and funding for energy saving activities through appropriate cost drivers. Schoute [19] proposed several $\mathrm{ABC}$ models for inter-firm cost accounting and a conceptual framework as there are no standards for the definition and composition of costs. Qian and Ben-Arieh [20] discussed how to handle such uncertainty as it relates to the feasibility and benefits of implementing an $\mathrm{ABC}$ system in an uncertain medical care environment by introducing a conceptual framework based on Fuzzy Logic and Monte Carlo Simulations. Meanwhile, Baykasoğlu and Kaplanoğlu [11] examined the associations between product diversity, usage of advanced manufacturing technologies and $\mathrm{ABC}$ adoption. To evaluate the profitability of each order of fulfilment policy and generate valuable cost information, Krug et al. [21] introduced a new cost management and decision support system by integrating system dynamics simulation and mixed-integer programming and incorporated them with ABC and Management. Due to competitive pressure forces from manufacturers to produce more products with shorter life spans and better quality, yet at a lower cost, Krug et al. [21] presented a cost-estimation model that linked ABC with the parametric cost representations of the design and development phases of machined rotational parts. Yereli [7] applied $\mathrm{ABC}$ to a land transportation company by integrating it with business process modelling and analytical hierarchy approach. Similarly, Shigaev [22] applied the ABC approach to give a better insight in the actual cost structure of a positron emission tomography procedure by defining the constituting components and simulating the impact of possible resource or practice changes. In the case of gall bladder surgeries, ABC approach is proven to be an effective cost management model that determined costs and evaluated financial performance across departments [23]. In a work by Jusoh and Miryazdi [24], the authors described the case of the realisation of a two-stage cost allocation scheme of $\mathrm{ABC}$ and related customer profitability report at a distribution company. The application of $\mathrm{ABC}$ in remanufacturing industries is important because the cost driver will change from a volume-based to an activity-based. The proposed costing could also enhance the control over overhead costs because product diversity has different 
activities required to perform it. Therefore, management could confidently make a better decision to either reject or remanufacture after looking from the top down of the analysis.

\section{METHODS AND MATERIALS}

This work is actually a continuation of the research done by Abu et al. [23] of a classified EOL crankshaft into rejected, repairable and remanufacturable. Generally, the ABC system includes allocation of indirect costs to centres, costs from centres to activities and costs from activities to cost objects. This work has focused on 35 units of crankshaft with six numbers of crankpins. To perform the method, the initial step is identifying the centres with their activities that give a major contribution to the production process. In order to reduce the complexity of $\mathrm{ABC}$ system in this work, it is sufficient by selecting only the critical centres and activities.

Secondly, resources cost is assigned to activity centres. This is actually done by estimating an amount of overhead for that year to be apportioned in percentage to those activity centres. The costs of the resources are already recorded in the existing accounting system including items such as wages, supplies and utilities cost. Then, activity centre cost is assigned to activities. The cost that has just been apportioned in the second stage should be apportioned to the different types of product in terms of percentages based on their activity load. Similarly, overhead would also be apportioned by using percentage for such categories as wages, depreciation, consumables, energy, building cost and other costs. Fourthly, the cost per unit of activity driver is estimated. An activity driver is a cost driver used to estimate the cost of an activity consumed by the cost object. The activity driver should be proportional to the activity cost or activities that consume costs. The final step is preparing a bill of activities for a unit of crankshaft. A cost object is any product for which management wants a separate measure of the cost. Cost per unit of activity driver would multiply with the annual quantity of cost driver consumed to obtain the total annual cost. The outcome is a total cost of each product that consists of a list of the activities used by the product and their costs.

\section{RESULTS AND DISCUSSION}

This work has divided the costing into six centres. The administration centre is very important because it managed the process of account receivables and payables. Corporate management centre is a driver of any businesses at the top level as it has the responsibility of acquiring sufficient resources for the organisation's operations. Although these activity centres are not directly influencing the remanufacturing operation of crankshafts, their indirect role in acquiring the core from domestic suppliers is important. The factory management centre provided the required space with sufficient facilities in an efficient manner, thus ensuring a lean operation. This centre provided the assistance for the remanufacturing centre to operate in an efficient manner. The role of the remanufacturing centre is to produce crankshafts as close to new as possible with a similar expected life span and one-year warranty. To achieve the necessary level of specialty and efficiency, the quality control centre ensured that the performance of the crankshafts met the client's requirements and characteristics according to the standard given by the OEM. Finally, the sales and dispatch centre managed the cost effective transporting of crankshafts to ensure the finished product is delivered to the client in satisfactory conditions. This work assumed that the resource costs allocated by the corporate management centre for crankshafts amounted to RM413,000. This would involve taking into consideration the 
categories of overheads such as wages, depreciations, consumables, energy, building costs and other costs. Table 1 shows the overhead apportionment from resource cost into six activity centres.

Table 1. Assigning resources cost to centres.

\begin{tabular}{|c|c|c|c|c|c|c|c|c|c|c|c|c|}
\hline \multirow[b]{2}{*}{$\begin{array}{l}\text { Overhead } \\
\text { category }\end{array}$} & \multicolumn{12}{|c|}{ Activity centre } \\
\hline & \multicolumn{2}{|c|}{$\begin{array}{l}\text { Administration } \\
(18 \%)\end{array}$} & \multicolumn{2}{|c|}{$\begin{array}{c}\text { Corporate } \\
\text { management } \\
(18 \%)\end{array}$} & \multicolumn{2}{|c|}{$\begin{array}{c}\text { Factory } \\
\text { management } \\
(12 \%) \\
\end{array}$} & \multicolumn{2}{|c|}{$\begin{array}{c}\text { Quality } \\
\text { control } \\
(18 \%) \\
\end{array}$} & \multicolumn{2}{|c|}{$\begin{array}{l}\text { Remanufacturing } \\
\qquad(24 \%)\end{array}$} & \multicolumn{2}{|c|}{$\begin{array}{l}\text { Sales and } \\
\text { dispatch } \\
(9 \%)\end{array}$} \\
\hline Wages & $70 \%$ & 52500 & $60 \%$ & 45000 & $66 \%$ & 33000 & $62 \%$ & 46500 & $47 \%$ & 46800 & $55 \%$ & 21000 \\
\hline Depreciations & $3 \%$ & 2500 & $2 \%$ & 1500 & $2 \%$ & 1000 & $8 \%$ & 6000 & $21 \%$ & 21250 & $3 \%$ & 1250 \\
\hline Consumables & $1 \%$ & 914 & $0 \%$ & 180 & $0 \%$ & 181 & $0 \%$ & 313 & $7 \%$ & 7319 & $1 \%$ & 500 \\
\hline Energy & $10 \%$ & 7500 & $4 \%$ & 3000 & $3 \%$ & 1500 & $2 \%$ & 1500 & $7 \%$ & 6600 & $4 \%$ & 1500 \\
\hline Building cost & $6 \%$ & 4500 & $3 \%$ & 2250 & $3 \%$ & 1250 & $2 \%$ & 1250 & $1 \%$ & 1250 & $3 \%$ & 1250 \\
\hline Other costs & $9 \%$ & 7086 & $31 \%$ & 23070 & $26 \%$ & 13069 & $26 \%$ & 19437 & $717 \%$ & 16781 & $33 \%$ & 12500 \\
\hline Total (RM) & & 75000 & & 75000 & & 50000 & & 75000 & & 100000 & & 38000 \\
\hline Grand total (RM) & & & & & & & & & & & & 413000 \\
\hline
\end{tabular}

The administration centre had 7 personnel that were mainly responsible for managing the process of accounts receivables and payables with a monthly compensation of RM625 each. Since the work area of this centre was within the office, this work expected depreciation expenses from computers, telephones, air conditioners, fax machines and printers to come out to approximately RM2,500 per month. This work also assumed that the centre used a large quantity of paper for documentations and renewed some formal workers' appearances with respect to the consumables, thus the total was RM914. Energy consumption was approximately RM625 per month. The building costs only covered the necessary renovations to ensure the remanufactured crankshaft can be produced efficiently.

The corporate management centre had 3 personnel who were mainly responsible for acquiring sufficient resources for the organisation's operations and for promoting the company's specialty at the global and domestic level. Their rates were RM1,250 per month each. This work expected depreciation to come from computers, air conditioners, telephones, fax machines and printers for an amount of approximately RM1,500 per month. This work also assumed that the centre used a small quantity of paper for documentation purposes and renewed some formal workers' appearances. With respect to the consumables, the total was RM180. Energy consumed in the form of electricity was approximately RM250 per month. The building costs only covered the necessary renovations to ensure that the remanufactured crankshafts can be produced efficiently.

The factory management centre had 1 leader, 1 assistant leader and 2 personnel who were mainly responsible for providing an efficient manner in terms of space with sufficient facilities to assist the remanufacturing centre to perform efficiently. Their rates were approximately RM1,000, RM750 and RM500 respectively per month. Since the work area of this centre was within the office as well, depreciation from computers, air conditioners, telephones, fax machines and printers was approximately RM1,000. This work also assumed the centre used a small quantity of paper for documentation and renewed some formal worker s' appearances and safety shoes, thus the consumables totalled up to RM180. Energy consumption amounted to approximately RM125 per month. The building cost allocations amounted to only RM1250 to cover any renovation when necessary. 
The quality control centre had 1 leader and 4 workers who were mainly responsible for ensuring that the crankshaft met the client's requirements and specifications according to the standards given by the OEM. Their rates were approximately RM875 and RM750 respectively per month. Since the work area of this centre was both inside and outside the office, this work expected that depreciation might come from computers, air conditioners, printers, and tools and equipment of inspection which totaled to approximately RM6,000. This work assumed that the centre used a small quantity of paper for documentation and renewed some formal workers' appearances, including safety shoes, tissues and goggles. Thus with respect to the consumables, the total was RM313. Energy consumed was approximately RM125 per month. The building cost was expected to be RM1,250 to cover any renovation when necessary as well.

The remanufacturing centre had 1 leader, 4 workers for grinding and polishing and 2 workers for the cleaning process who were mainly responsible to produce the crankshafts as close to new as possible. Their compensation rate was approximately RM1,000, RM500 and RM450 respectively per month. Since the work area of this centre was both inside and outside the office, this work expected depreciation from computers, air conditioners, telephones, fax machines and printers with provision of approximately RM21,250. Grinding, polishing and cleaning machines maintenance was approximately RM15,000 while maintenance for the tools setup was RM5,000. Then, this work also assumed that the centre used a small quantity of paper for documentation, renewed some formal workers' appearances, and made allocations for a stone grinder, grid paper, detergent for the cleaning process, safety shoes and tissues. With respect to the consumables, the total was RM7,319. Energy usage for office, grinding machines, polishing machines and cleaning amounted to a total cost of approximately RM6,600. The building cost was RM1,250 which covered any renovation when necessary.

Table 2. Assigning administration centre cost to activities

\begin{tabular}{|c|c|c|c|c|}
\hline \multirow{3}{*}{$\begin{array}{l}\text { Overhead } \\
\text { category }\end{array}$} & \multicolumn{4}{|c|}{ Administration centre activities } \\
\hline & $\begin{array}{l}\text { Process } \\
\text { receivable }\end{array}$ & Process payable & $\begin{array}{c}\text { Operating IT } \\
\text { system }\end{array}$ & $\begin{array}{c}\text { Preparing } \\
\text { payroll }\end{array}$ \\
\hline & $20 \%$ & $32 \%$ & $35 \%$ & $13 \%$ \\
\hline Wages & 10500 & 16800 & 18375 & 6825 \\
\hline Depreciation & 500 & 800 & 875 & 325 \\
\hline Consumables & 183 & 293 & 320 & 119 \\
\hline Energy & 1500 & 2400 & 2625 & 975 \\
\hline Building cost & 900 & 1440 & 1575 & 585 \\
\hline Other cost & 1417 & 2268 & 2480 & 921 \\
\hline Total cost & 15000 & 24000 & 26250 & 9750 \\
\hline
\end{tabular}

The sales and dispatch centre had 1 leader and 2 workers who were mainly responsible for determining the most cost effective transporting so as to ensure the that crankshafts will be delivered back to the client in a satisfactory condition. Their rates were approximately RM750 and RM500 respectively per month. Since the work area of this centre was within the office, this work expected depreciation to come from computers, air conditioners, telephones, fax machines and printers at approximately RM1,250. This work also assumed that the centre used small quantities of paper for documentation and renewed some formal workers' appearances including safety shoes. With respect to the consumables, the total was RM500. Energy used such as electricity was approximately RM125 per month. The building cost was RM1,250 and it covered 
any renovation where necessary. The overhead apportionment for the administration centre was RM75,000. From that amount, the apportionment as shown in Table 2 is based on the requirement for each activity. According to the processing of receivables activity, 7 staff were responsible for managing the number of invoices through the account receivables at the rate of RM125 per month. The resource driver for depreciation was the electric machines used by the activity for scanning the invoice and receiving the invoice through email respectively with the cost of RM500 per year. Then, the resource driver of consumables was used by the activity such as papers used for the printing of invoice and other supporting documents to be submitted to the manager and the head of finance with the apportionment of RM183 per year. The resource driver of energy used kilowatt for this activity and is allocated about RM1500 per year. The resource driver of building cost for any renovation made when necessary was RM900 per year. The overhead apportionment for the Corporate management centre was RM75 000. From that amount, it is apportioned as shown in Table 3.

Table 3. Assigning corporate management centre costs to activities.

\begin{tabular}{|c|c|c|c|c|}
\hline \multirow{3}{*}{$\begin{array}{l}\text { Overhead } \\
\text { category }\end{array}$} & \multicolumn{4}{|c|}{ Corporate management centre activities } \\
\hline & $\begin{array}{l}\text { Providing } \\
\text { continuity for } \\
\text { organisation }\end{array}$ & $\begin{array}{l}\text { Appointing a } \\
\text { chief executive }\end{array}$ & $\begin{array}{l}\text { Governing the } \\
\text { organisation }\end{array}$ & $\begin{array}{l}\text { Acquiring } \\
\text { resources for } \\
\text { organisation } \\
\text { operation }\end{array}$ \\
\hline & $26 \%$ & $23 \%$ & $20 \%$ & $31 \%$ \\
\hline Wages & 11700 & 10350 & 9000 & 13950 \\
\hline Depreciation & 390 & 345 & 300 & 465 \\
\hline Consumables & 47 & 42 & 36 & 56 \\
\hline Energy & 780 & 690 & 600 & 930 \\
\hline Building cost & 585 & 518 & 450 & 698 \\
\hline Other cost & 5998 & 5306 & 4614 & 7152 \\
\hline Total cost & 19500 & 17250 & 15000 & 23250 \\
\hline
\end{tabular}

Providing continuity for organisational activities means the board of directors ensured that the company maintains the trust of the public on the global and domestic fronts so that the company will continue to produce quality remanufactured products. 3 staff with different roles were responsible for maintaining this continuity with a rate of RM325 per month. The depreciation of overhead at RM390 covered computers, printers, telephones, fax machines, projectors and air conditioners used for servicing. The overhead apportioned for consumables used for printing documentation was RM47 per year. The machines that utilised electricity are allocated about RM780 per year. About RM585 is apportioned to building costs as attraction to show that the company had a serious commitment to the business. The overhead apportionment for the factory management centre was RM50 000 with different apportionments as shown in Table 4.

The program production activity had the responsibility to provide worker schedule for daily operations. 1 head of factory, 1 assistant of head factory and 1 one worker were responsible for crane operation and another was responsible for the forklift with rates of RM330, RM248, RM165 and RM165 respectively. The depreciation was RM330 which covered computers, printers, telephones, fax machines and air conditioners used for servicing. The overhead apportioned for consumables for printing documentation was RM60 per year. The machines that utilised electricity are allocated RM495 and RM413 for the building costs to setup a more effective remanufacturing. 
The overhead apportionment for the quality control centre was RM75 000 as shown in Table 5 .

Table 4. Assigning factory management centre cost to activities.

\begin{tabular}{|c|c|c|c|c|}
\hline \multirow{3}{*}{$\begin{array}{l}\text { Overhead } \\
\text { category }\end{array}$} & \multicolumn{4}{|c|}{ Factory management centre activities } \\
\hline & $\begin{array}{l}\text { Program } \\
\text { production }\end{array}$ & $\begin{array}{l}\text { Expediting } \\
\text { order }\end{array}$ & $\begin{array}{c}\text { Managing } \\
\text { plant }\end{array}$ & $\begin{array}{c}\text { Training } \\
\text { production } \\
\text { personnel }\end{array}$ \\
\hline & $33 \%$ & $28 \%$ & $26 \%$ & $13 \%$ \\
\hline Wages & 10980 & 9240 & 8580 & 4290 \\
\hline Depreciation & 330 & 280 & 260 & 130 \\
\hline Consumables & 60 & 51 & 47 & 24 \\
\hline Energy & 495 & 420 & 413 & 195 \\
\hline Building cost & 413 & 350 & 325 & 163 \\
\hline Other cost & 4313 & 3659 & 3398 & 1699 \\
\hline Total cost & 16500 & 14000 & 13000 & 6500 \\
\hline
\end{tabular}

Table 5. Assigning quality control centre cost to activities.

\begin{tabular}{lccccc}
\hline & \multicolumn{5}{c}{ Quality control centre activities } \\
\cline { 2 - 6 } \multicolumn{1}{c}{$\begin{array}{c}\text { Overhead } \\
\text { category }\end{array}$} & $\begin{array}{c}\text { Tools and } \\
\text { equipment } \\
\text { maintenance }\end{array}$ & $\begin{array}{c}\text { Hardness } \\
\text { measurement }\end{array}$ & $\begin{array}{c}\text { Inspection } \\
\text { process }\end{array}$ & $\begin{array}{c}\text { Leak } \\
\text { testing }\end{array}$ & $\begin{array}{c}\text { Training } \\
\text { on quality }\end{array}$ \\
\cline { 2 - 6 } & $25 \%$ & $15 \%$ & $20 \%$ & $23 \%$ & $17 \%$ \\
\hline Wages & 11625 & 6975 & 9300 & 10695 & 7905 \\
Depreciation & 1500 & 900 & 1200 & 1380 & 1020 \\
Consumables & 78 & 47 & 63 & 72 & 53 \\
Energy & 375 & 225 & 300 & 345 & 255 \\
Building cost & 313 & 188 & 250 & 288 & 213 \\
Other cost & 4859 & 2916 & 3889 & 4471 & 3304 \\
\hline Total cost & 18750 & 11250 & 15000 & 17250 & 1275075000 \\
\hline
\end{tabular}

The tools and equipment maintenance activity was responsible to ensure that all equipment required for production was operating at 100\% efficiency at all times. 1 head of quality and 4 workers were responsible with the rates of RM219 and RM188 per month respectively. The depreciation apportionment was RM1500 which covered computers, printers, telephones, fax machines, air conditioners, and tools and equipment used during inspection for servicing. The overhead apportioned for consumables used such as papers, laser cartridge powder, coveralls, tissues, goggles and safety shoes was RM78 per year. The machines that utilised electricity are allocated about RM375 per year. About RM313 is apportioned to building costs to make the remanufacturing more efficient. The overhead apportionment for the remanufacturing centre was RM100 000 as shown in Table 6.

The grinding activity was responsible for grinding the crankpins according to the standards given by the OEM after being validated by the quality control centre. 1 head of remanufacturing centre, 4 workers responsible on grinding and polishing, and 2 workers responsible for cleaning are given the rates of RM330, RM165 and RM149 respectively. The depreciation of overheads was RM7013 covering computers, printers, telephones, fax machines, air conditioners, machine maintenance and tools required for setup for 
servicing when necessary. The overheads apportioned for consumables used such as papers, laser cartridge powder, coveralls, tissues, goggles, safety shoes, grinder stones, grid paper and detergents was RM2413 per year. Those grinding, polishing and cleaning machines that utilised electricity are measured in kilowatts and allocated about RM2178 per year. About RM413 is apportioned to building costs for a better setup to make the remanufacturing more efficient. The overhead apportionment for the sales and dispatch centre was RM38 000 as shown in Table 7.

Table 6. Assigning remanufacturing centre cost to activities.

\begin{tabular}{|c|c|c|c|c|}
\hline \multirow{3}{*}{ Overhead category } & \multicolumn{3}{|c|}{ Remanufacturing centre activities } & \\
\hline & Grinding & Polishing & Cleaning & \\
\hline & $33 \%$ & $32 \%$ & $35 \%$ & \\
\hline Wages & 15444 & 14976 & 16380 & \\
\hline Depreciation & 7013 & 6800 & 7438 & \\
\hline Consumables & 2413 & 2340 & 2567 & \\
\hline Energy & 2178 & 2112 & 2310 & \\
\hline Building cost & 413 & 400 & 438 & \\
\hline Other cost & 5540 & 5373 & 5869 & \\
\hline Total cost & 33000 & 32000 & 35000 & 100000 \\
\hline
\end{tabular}

Table 7. Assigning sales and dispatch centre cost to activities.

\begin{tabular}{|c|c|c|c|c|}
\hline \multirow{3}{*}{$\begin{array}{l}\text { Overhead } \\
\text { category }\end{array}$} & \multicolumn{4}{|c|}{ Sales and dispatch centre activities } \\
\hline & $\begin{array}{c}\text { Process sales } \\
\text { order }\end{array}$ & Packaging plan & $\begin{array}{c}\text { Packaging } \\
\text { training }\end{array}$ & \\
\hline & $23 \%$ & $40 \%$ & $37 \%$ & \\
\hline Wages & 4830 & 8400 & 7770 & \\
\hline Depreciation & 288 & 500 & 463 & \\
\hline Consumables & 39 & 68 & 394 & \\
\hline Energy & 345 & 600 & 555 & \\
\hline Building cost & 288 & 500 & 463 & \\
\hline Other cost & 2951 & 5133 & 4416 & \\
\hline Total cost & 8740 & 15200 & 14060 & 38000 \\
\hline
\end{tabular}

According to the process sales order activity, the operation was responsible for generating documents that authorised sale of the specified item that was in-house that has not been shipped yet. 1 head of sale and dispatch centre and 2 workers with rates of RM173 and RM115 respectively are involved in this activity. The depreciation of overhead was RM288 covering computers, printers, telephone, fax machine and air conditioners used for servicing when necessary. The overheads apportioned for consumables such as papers, laser powder printer used for printing documentation, coveralls and safety shoes was RM39 per year.

The machines that utilised electricity are measured in kilowatts and allocated about RM345 per year. About RM288 is apportioned to building costs for a better setup to make the remanufacturing more efficient. The resource driver of other costs in this activity was the overtime of labour spent on the activity. 
Table 8. Activities and activity cost per unit of activity drivers.

\begin{tabular}{|c|c|c|c|}
\hline Activity centre with activities & $\begin{array}{l}\text { Activity } \\
\text { cost }\end{array}$ & $\begin{array}{c}\text { Predict } \\
\text { quantity of } \\
\text { activity driver }\end{array}$ & $\begin{array}{l}\text { Cost per unit of } \\
\text { activity driver } \\
\text { (RM) }\end{array}$ \\
\hline \multicolumn{4}{|l|}{ Administration } \\
\hline Process receivables & 15000 No. of invoices & 800 units & 18.75 \\
\hline Process payables & 24000 No. of purchase orders & 750 units & 32.00 \\
\hline Operating IT system & 26250 No. of CPU time-hours & 9000 hours & 2.92 \\
\hline Preparing payroll & $\frac{9750}{75000}$ No. of payslips & 300 persons & 32.50 \\
\hline \multicolumn{4}{|l|}{ Corporate management } \\
\hline $\begin{array}{l}\text { Providing continuity for } \\
\text { organisation }\end{array}$ & 19500 None available & $\begin{array}{l}\text { Facility } \\
\text { activity } \\
\text { Facility }\end{array}$ & - \\
\hline Appointing a chief executive & 17250 None available & $\begin{array}{l}\text { activity } \\
\text { Facility }\end{array}$ & - \\
\hline Governing the organisation & 15000 None available & $\begin{array}{l}\text { activity } \\
\text { Facility }\end{array}$ & - \\
\hline Acquiring resources & $\frac{23250}{75000}$ None available & activity & - \\
\hline \multicolumn{4}{|l|}{ Factory management } \\
\hline Program production & 16500 No. of man hours & 26000 hours & 0.64 \\
\hline \multirow[t]{4}{*}{ Expediting order } & $\begin{array}{l}14000 \text { No. of grinding machines } \\
\text { No. of polishing }\end{array}$ & 12 units & 291.67 \\
\hline & machines & 12 units & 291.67 \\
\hline & No. of cleaning machines & 11 units & 318.18 \\
\hline & No. of man power & 20 persons & 175.00 \\
\hline Managing plant & 13000 No. of crankshafts & 450 units & 28.89 \\
\hline Training production personnel & $\frac{6500}{50000}$ No. of training-hours & 550 hours & 11.82 \\
\hline \multicolumn{4}{|l|}{ Quality control } \\
\hline Tools and equipment maintenance & 18750 No. of tools-hours & 2700 hours & 6.95 \\
\hline Hardness measurement & 11250 No. of crankshafts & 700 units & 16.07 \\
\hline Inspection process & 15000 No. of crankpins & 3100 units & 4.84 \\
\hline Leak testing & 17250 No. of testing-hours & 5000 hours & 3.45 \\
\hline Training on quality & $\frac{12750}{75000}$ No. of training-hours & 950 hours & 13.42 \\
\hline \multicolumn{4}{|l|}{ Remanufacturing } \\
\hline \multirow[t]{2}{*}{ Grinding } & 33000 No. of machine hours & 11000 hours & 1.50 \\
\hline & No. of setup hours & 8320 hours & 1.98 \\
\hline \multirow[t]{2}{*}{ Polishing } & 32000 No. of machine hours & 11000 hours & 1.46 \\
\hline & No. of setup hours & 7780 hours & 2.06 \\
\hline \multirow[t]{3}{*}{ Cleaning } & 35000 No. of machine hours & 4000 hours & 4.38 \\
\hline & No. of setup hours & 8240 hours & 2.13 \\
\hline & 100000 & & \\
\hline \multicolumn{4}{|l|}{ Sales and dispatch } \\
\hline Process sales order & 8740 No. of sales orders & 250 units & 34.96 \\
\hline Packaging plan & 15200 No. of man hours & 5160 hours & 2.95 \\
\hline Packaging training & $\frac{14060}{38000}$ No. of training-hours & 880 hours & 15.98 \\
\hline Total cost & 413000 & & \\
\hline
\end{tabular}

Activity driver is a cost driver used to estimate the costs of an activity consumed by the cost objects. In selecting an activity driver, there must be a linear relationship between the activity costs and the activity drivers. Estimation of the quantity of activity driver is obtained for each activity for the year so that the cost per unit of activity driver 
may be calculated as shown in Table 8 . As agreed by [18], resource costs are assigned to various activities; using resource drivers, the factors are chosen to approximate the consumption of resources used in activities. Thus, an activity cost pool provides the total costs associated with a particular activity. An activity centre is composed of related activities, usually clustered according to function or process. By focusing on remanufacturing centres, the longer the machine and setup hours, the larger the cost of grinding activity. Continuous usage of the grinding machines to remove excess metal on the surface of crankpin indicated that maintenance or depreciation cost would increase. Meanwhile, the protective personal equipment used such as coverall, safety shoe and goggle would also increase the consumable cost. Similarly, this happened to the polishing activity as well. The longer the machine and setup hour, the larger the cost of cleaning activity. The activity also increased the depreciation, consumable and energy costs.

Table 9. Activity-based product cost (Caterpillar).

\begin{tabular}{|c|c|c|c|c|c|}
\hline Activity level & Activity & $\begin{array}{l}\text { Cost per unit } \\
\text { of activity } \\
\text { driver (RM) }\end{array}$ & $\begin{array}{c}\text { Annual quantity of } \\
\text { cost driver } \\
\text { consumed }\end{array}$ & $\begin{array}{c}\text { Annual } \\
\text { cost }(\mathrm{RM})\end{array}$ & $\begin{array}{l}\text { Cost per unit } \\
\text { of product } \\
(\mathrm{RM})\end{array}$ \\
\hline Unit & Measure hardness & 16.07 & 35 units & 562.54 & \\
\hline Unit & Inspection process & 4.84 & 210 units & 1015.88 & \\
\hline Unit & Grinding-machine hours & 1.50 & 336 hours & 504.00 & \\
\hline Unit & Grinding-setup hours & 1.98 & 714 hours & 1415.50 & \\
\hline Unit & Polishing-machine hours & 1.46 & 84 hours & 122.22 & \\
\hline Unit & Polishing-setup hours & 2.06 & 672 hours & 1382.64 & \\
\hline Unit & Cleaning-machine hours & 4.38 & 294 hours & 1286.25 & \\
\hline Unit & Cleaning-setup hours & 2.13 & 630 hours & 1338.75 & \\
\hline Unit & Perform leak testing & 3.45 & 147 hours & 507.15 & \\
\hline Unit & Packing plan & 2.95 & 66.5 hours & 195.84 & \\
\hline Batch & $\begin{array}{l}\text { Program production } \\
\text { Expedite order-grinding }\end{array}$ & 0.64 & 2943.5 hours & 1869.12 & \\
\hline Batch & $\begin{array}{l}\text { machines } \\
\text { Expedite order-polishing }\end{array}$ & 291.67 & 2 units & 583.34 & \\
\hline Batch & $\begin{array}{l}\text { machines } \\
\text { Expedite order-cleaning }\end{array}$ & 291.67 & 2 units & 583.34 & \\
\hline Batch & machines & 318.18 & 2 units & 636.37 & \\
\hline Batch & Expedite order-man powers & 175.00 & 4 persons & 700.00 & \\
\hline Facility & Manage plant & 28.89 & 35 units & 1011.15 & \\
\hline Total remanuf & facturing activity cost & & & 13714.07 & 391.83 \\
\hline Unit & $\begin{array}{l}\text { Tools and equipment } \\
\text { maintenance }\end{array}$ & 6.95 & 59.5 hours & 413.23 & \\
\hline Batch & Process receivables & 18.75 & 160 units & 3000.00 & \\
\hline Batch & Process payables & 32.00 & 160 units & 5120.00 & \\
\hline Batch & Operate IT system & 2.92 & 2112 hours & 6156.48 & \\
\hline Batch & Prepare payroll & 32.50 & 26 persons & 845.00 & \\
\hline Batch & $\begin{array}{l}\text { Process sales order } \\
\text { Training production }\end{array}$ & 34.96 & 100 units & 3496.00 & \\
\hline Facility & personnel & 11.82 & 72 hours & 850.86 & \\
\hline Facility & Training on quality & 13.42 & 72 hours & 966.24 & \\
\hline Facility & Packaging training & 15.98 & 72 hours & 1150.38 & \\
\hline \multicolumn{2}{|c|}{ Total non-remanufacturing activity cost } & & & 21998.19 & 628.52 \\
\hline \multicolumn{2}{|c|}{ Total crankshaft cost per unit } & & & & 1020.35 \\
\hline
\end{tabular}

A bill of activities is prepared for the Caterpillar engine model as shown in Table 9. The crankshaft has an estimated cost of RM1,020.35 per unit, after taking into consideration 35 units of crankshaft with six crankpins. As agreed by Esmalifalak et al. 
[18], the costs in each activity cost pool are assigned to cost objects by an adequate activity driver used to measure the consumption activities by the cost objects. From the costing structure, it can also be seen that ABC had better allocation of overhead to the product [24]. Such costings which have been estimated are influenced by a few factors such as complexity of crankshaft, quantity of crankshaft required, number of crankpins per crankshaft and resource cost. The higher the complexities factored in such as size, weight and hardness of the crankshaft, the longer the process duration during setups and grinding, setups and polishing, setups and cleaning, leak testing, packaging, program production and maintenance. It is therefore understandable that remanufactured crankshaft has become more costly. The complexity of crankshaft was gradually increasing, starting with Caterpillar, Man, Perkins, Hatz, Detroit and finally with Mtu183 as shown in Table 10.

Table 10 Complexity influencing the cost.

\begin{tabular}{lcccccc}
\hline & \multicolumn{7}{c}{ Independent factor } \\
\cline { 2 - 7 } \multicolumn{1}{c}{ Activity } & Caterpillar & Detroit & Hatz & Man & MTU183 & Perkins \\
\hline Grinding-machine (hour) & 1.6 & 2.3 & 2.1 & 1.8 & 2.5 & 2.0 \\
Grinding-setup (hour) & 3.4 & 4.2 & 4.0 & 3.6 & 4.4 & 3.8 \\
Polishing-machine (hour) & 0.4 & 0.8 & 0.7 & 0.5 & 0.9 & 0.6 \\
Polishing-setup (hour) & 3.2 & 4.0 & 3.8 & 3.4 & 4.2 & 3.6 \\
Cleaning-machine (hour) & 1.4 & 2.2 & 2.0 & 1.6 & 2.4 & 1.8 \\
Cleaning-setup (hour) & 3.0 & 3.8 & 3.6 & 3.2 & 4.0 & 3.4 \\
Perform leak testing (hour) & 0.7 & 1.1 & 1.0 & 0.8 & 1.2 & 0.9 \\
Packing plan (hour) & 1.9 & 2.7 & 2.5 & 2.1 & 2.9 & 2.3 \\
Program production (hour) & 2943.5 & 2212.7 & 784.3 & 6437.4 & 2394.7 & 1690.5 \\
Manage plant (unit) & 35 & 29 & 11 & 84 & 39 & 25 \\
Tools and equipment maintenance (hour) & 1.7 & 2.1 & 2.0 & 1.8 & 2.2 & 1.9 \\
Process receivables (unit) & 160 & 200 & 193 & 179 & 240 & 184 \\
Process payables (unit) & 160 & 200 & 193 & 179 & 240 & 184 \\
Process sales order (unit) & 100 & 140 & 130 & 110 & 150 & 120 \\
\hline
\end{tabular}

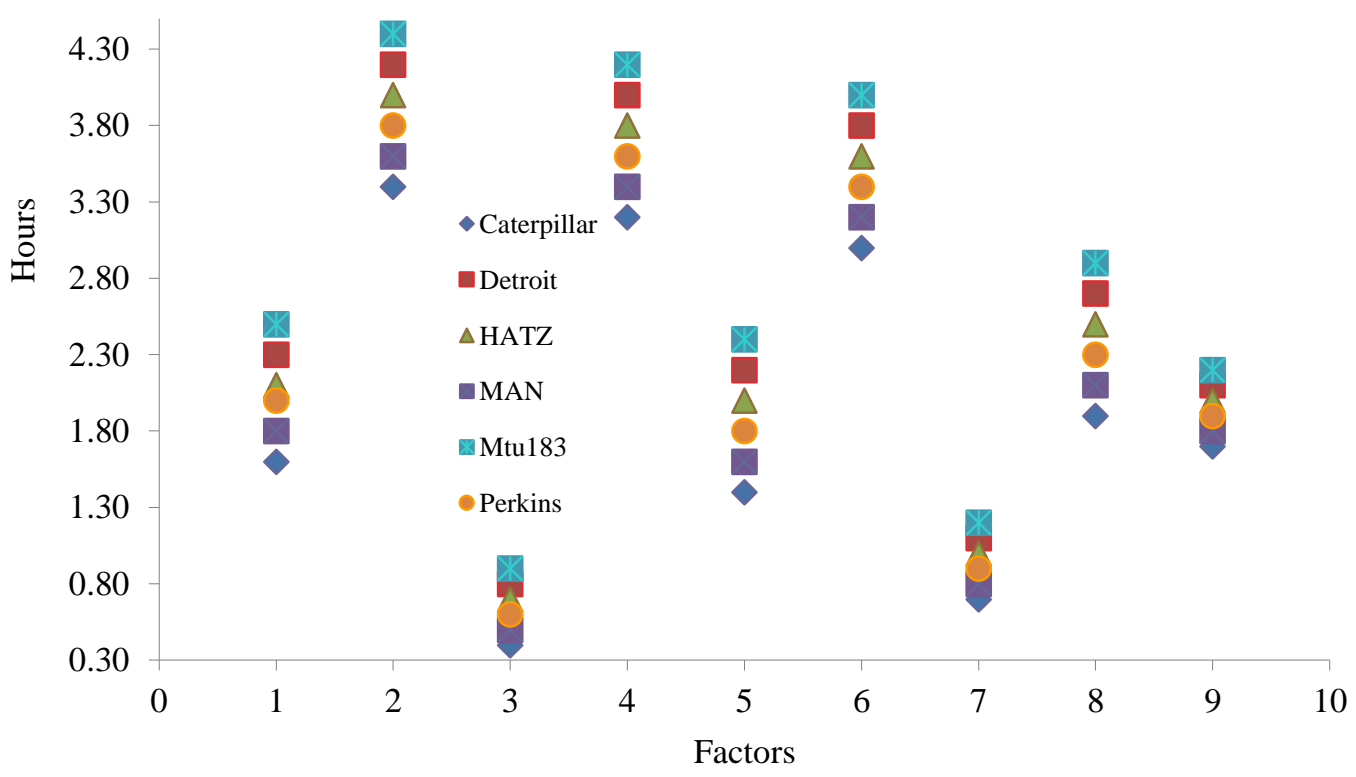

Figure 1. Complexity influencing the cost. 
Obviously, their pattern can be seen in Figure 1 by considering setup and grinding, setup and polishing, setup and cleaning, leak testing, packaging and maintenance factors. In addition, this work observed that through the implementation of the $\mathrm{ABC}$ system, the higher quantity of crankshaft required for the remanufacturing process, the cheaper the cost produced. For example, the Man engine model had the highest quantity of crankshaft with 84 units, thus the cost per unit was RM609.50, whereas the Hatz engine model had the lowest quantity of crankshaft with 11 units, thus the cost per unit was RM2727.72. This means that overhead costs are shifted from a high volume to a low volume because the low volume of crankshaft often requires a more specialised handling. Several engine models has identified their critical crankpin. From that, it has also been proven that the higher quantity of crankpins required for the remanufacturing process, the lower the costs produced. For instance, the Caterpillar engine model had the highest quantity of critical crankpin with six units, while the Mtu183 engine model had the lowest quantity of critical crankpin with three units. For the business to be a worthwhile cost, resources must be optimised as much as possible and apportioned to those centres, activity cost pools, and activity driver. Eventually, the cost will become reliable.

\section{CONCLUSIONS}

This work has successfully shown the characteristics of the ABC system which is proven to be better in the allocation of overhead on remanufactured crankshaft. The overhead is apportioned based on the number of activities required. According to Table 9, the cost has been divided into remanufacturing and non-remanufacturing which highlighted the strength of the ABC system. ABC is believed to be a cure for the shortcomings of TCA: production that is too late, too aggregated and too distorted to be relevant for managers' planning and control decisions. This work can be appointed as evidence to convince among industrial practitioners that the $\mathrm{ABC}$ system is more systematic in order to produce the cost of product. This work also recommended the use of multiple critical cost drivers during the cost pool in order to achieve greater accuracy of real cost.

\section{ACKNOWLEDGEMENTS}

The authors would like to be obliged to Universiti Malaysia Pahang and Universiti Teknologi Malaysia for providing financial assistance under RDU170387.

\section{REFERENCES}

[1] Cai ZH, Zhang P, Liang ZJ. Novel remanufacturing technology as an alternative to maintenance for diesel engine and its benefit analysis. Advanced Materials Research: Trans Tech Publ; 2011. p. 435-9.

[2] Zhang T, Chu J, Wang X, Liu X, Cui P. Development pattern and enhancing system of automotive components remanufacturing industry in china. Resources, Conservation and Recycling. 2011;55:613-22.

[3] Omer AM. Built environment: Relating the benefits of renewable energy technologies. International Journal of Automotive and Mechanical Engineering. 2012;5:561-75.

[4] Andrew-Munot M, Ibrahim RN. Remanufacturing process and its challenges. Journal of Mechanical Engineering and Sciences. 2013;4:488-95. 
[5] Tsai W-H, Hung S-J. Dynamic pricing and revenue management process in internet retailing under uncertainty: An integrated real options approach. Omega. 2009;37:471-81.

[6] Kallunki J-P, Silvola H. The effect of organizational life cycle stage on the use of activity-based costing. Management accounting research. 2008;19:62-79.

[7] Yereli AN. Activity-based costing and its application in a turkish university hospital. AORN journal. 2009;89:573-91.

[8] Askarany D, Yazdifar H, Askary S. Supply chain management, activity-based costing and organisational factors. International Journal of Production Economics. 2010;127:238-48.

[9] Satoglu SI, Durmusoglu MB, Dogan I. Evaluation of the conversion from central storage to decentralized storages in cellular manufacturing environments using activity-based costing. International Journal of Production Economics. 2006;103:616-32.

[10] Carli G, Canavari M. Introducing direct costing and activity based costing in a farm management system: A conceptual model. Procedia Technology. 2013;8:397-405.

[11] Baykasoğlu A, Kaplanoğlu V. Application of activity-based costing to a land transportation company: A case study. International Journal of Production Economics. 2008;116:308-24.

[12] Ramasamy D, Yuan GC, Abu Bakar R, Zainal ZA. Validation of road load characteristic of a sub-compact vehicle by engine operation. International Journal of Automotive and Mechanical Engineering (IJAME). 2014;9:1820-31.

[13] Khataie AH, Bulgak AA, Segovia JJ. Activity-based costing and management applied in a hybrid decision support system for order management. Decision Support Systems. 2011;52:142-56.

[14] Tsai W-H, Chen H-C, Leu J-D, Chang Y-C, Lin TW. A product-mix decision model using green manufacturing technologies under activity-based costing. Journal of Cleaner Production. 2013;57:178-87.

[15] Ríos-Manríquez M, Colomina CIM, Pastor MLR-V. Is the activity based costing system a viable instrument for small and medium enterprises? The case of mexico. Estudios gerenciales. 2014;30:220-32.

[16] Tsai W-H, Yang C-H, Chang J-C, Lee H-L. An activity-based costing decision model for life cycle assessment in green building projects. European Journal of Operational Research. 2014;238:607-19.

[17] Schulze M, Seuring S, Ewering C. Applying activity-based costing in a supply chain environment. International Journal of Production Economics. 2012;135:716-25.

[18] Esmalifalak H, Albin MS, Behzadpoor M. A comparative study on the activity based costing systems: Traditional, fuzzy and monte carlo approaches. Health Policy and Technology. 2015;4:58-67.

[19] Schoute M. The relationship between product diversity, usage of advanced manufacturing technologies and activity-based costing adoption. The British Accounting Review. 2011;43:120-34.

[20] Qian L, Ben-Arieh D. Parametric cost estimation based on activity-based costing: A case study for design and development of rotational parts. International Journal of Production Economics. 2008;113:805-18. 
[21] Krug B, Van Zanten A, Pirson A-S, Crott R, Vander Borght T. Activity-based costing evaluation of $[18 \mathrm{~F}]$-fludeoxyglucose production. European journal of nuclear medicine and molecular imaging. 2008;35:80-8.

[22] Shigaev A. Accounting entries for activity-based costing system: The case of a distribution company. Procedia Economics and Finance. 2015;24:625-33.

[23] Abu M, Jamaluddin K, Zakaria M. Classification of crankshaft remanufacturing using mahalanobis-taguchi system. International Journal of Automotive and Mechanical Engineering. 2016; 13(2):3413-22.

[24] Jusoh R, Miryazdi S. The influence of technological and environmental factors on the diffusion of activity-based costing in iran. Tékhne. 2015;13:95-109. 